IRA-International Journal of Management \& Social Sciences

ISSN 2455-2267; Vol.10, Issue 03 (March 2018)

Pg. no. 100-106.

Institute of Research Advances

http://research-advances.org/index.php/RAJMSS

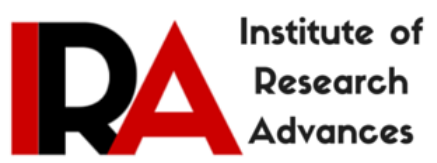

\title{
Impact of Demonetization on Small Businesses in Indian Economy - an Empirical Study on Small Businesses at Cooch Behar District, West Bengal
}

\author{
Madhuchandra Bhaduri \\ Assistant Professor, Cooch Behar Govt. Engineering College, Cooch Behar, India.
}

Type of Review: Peer Reviewed.

DOI: http://dx.doi.org/10.21013/jmss.v10.n3.p2

\section{How to cite this paper:}

Bhaduri, M. (2018). Impact of Demonetization on Small Businesses in Indian Economy - an Empirical Study on Small Businesses at Cooch Behar District, West Bengal. IRA-International Journal of Management \& Social Sciences (ISSN 2455-2267), 10(3), 100-106. doi:http://dx.doi.org/10.21013/jmss.v10.n3.p2

(C) Institute of Research Advances.

\section{(cc) BY-NC}

This work is licensed under a Creative Commons Attribution-Non Commercial 4.0 International License subject to proper citation to the publication source of the work.

Disclaimer: The scholarly papers as reviewed and published by the Institute of Research Advances (IRA) are the views and opinions of their respective authors and are not the views or opinions of the IRA. The IRA disclaims of any harm or loss caused due to the published content to any party.

Institute of Research Advances is an institutional publisher member of Publishers Inter Linking Association Inc. (PILA-CrossRef), USA. The institute is an institutional signatory to the Budapest Open Access Initiative, Hungary advocating the open access of scientific and scholarly knowledge. The Institute is a registered content provider under Open Access Initiative Protocol for Metadata Harvesting (OAI-PMH).

The journal is indexed \& included in WorldCat Discovery Service (USA), CrossRef Metadata Search (USA), WorldCat (USA), OCLC (USA), Open J-Gate (India), EZB (Germany) Scilit (Switzerland), Airiti (China), Bielefeld Academic Search Engine (BASE) of Bielefeld University, Germany, PKP Index of Simon Fraser University, Canada. 


\begin{abstract}
November $8^{\text {th }}, 2016$ was a path breaking day in Indian economy when Govt. of India has demonetized the high value currency notes and replaced with new notes of Rs.500 and Rs.2000. This move Govt. was taken to clean the black money from the market, to inspire digital economy and to reduce the 'Cash' payment culture of some people for tax evasion. The overnight decision changed the life of many people in India. Thousands of people they waited in long queues in front of Banks, ATMs for money. Entire social life of people throughout the country got distracted. Many poor daily wage workers were left with no job and income as owners were unable to pay their daily wage because of less cash, around 15 lakh jobs have been obsolete during this one year.
\end{abstract}

Despite Govt. of India has taken a bold step to make India corruption free and inspire the people in cashless transaction but after one year can we say India is really corruption free? Can we observe any significant improvement in cashless transactions? Can we see the digital payments have significantly improved for common general man?

Many reports stated that Country's automobile and real estate sectors are highly affected and World Bank has downgraded the Indian economy's growth forecast as sharp falls. The empirical findings suggest that the impact of demonetization on GDP growth during Q3 and Q4 of 2016-17 was mostly felt in construction and real estate, but the good thing was that because of stronger growth in manufacturing, agriculture, mining and electricity the overall impact on gross domestic product growth was modest.

Many reports stated that small traders have immensely affected after demonetization because of the cash crunch and lack of infrastructure like digital payment system etc. Small traders in retail sector (grocery shops etc), service sector (restaurants, nursing homes etc.), gems and jewellery, small traders in agricultural products, SMEs, small dealers, professionals like doctors, lawyers etc, have highly affected because of demonetization during last one year. So my objective to find out whether the small traders have really affected or not. If they are affected then how they have affected?

The main objective of this paper is to study the impact of demonetization on the small scale traders at Cooch Behar District of West Bengal and how it affected their business. As we all know that Cooch Behar is the princely state of West Bengal which is located very near to Assam, Bhutan and Siliguri region. As a district town Cooch Behar has a high significance in businesses with Northeast, Siliguri and Bhutan. I prepared a questionnaire and surveyed to 50 small scale businessmen at Cooch Behar district and tried to find their perception on demonetization and its impacts on their businesses during last one year. The study at Cooch Behar district may reflect the status of small traders for entire country. Another objectives I have kept here to study whether demonetization really eradicated corruption from India and whether demonetization has changed the behavior of the citizens of the country in cashless transactions?

\title{
Introduction
}

Demonetization is the act or process of removing the legal status of currency unit. On Nov.8, 2016, Rs 500 and Rs1000 were demonetized with the intention to mitigate corruption, tax evasion, to remove counterfeit currency and to fight against terrorism. The intention was no doubt appreciable but this scheme has shown a great impact on Indian economy as this is a cash transaction oriented economy in almost all its business activities and there is one of the highest level of currencies in circulation over 12 percent of GDP and 87 Percent of this cash is in the form of Rs 500 and Rs 1000 notes in our country. After this overnight decision of demonetization, millions of Indians suffered as it hit on the body blow of economic activities in Indian economy specially in the vast areas of rural economy. Several deaths happened due to inconvenience caused for the rush to exchange cash to banks, ATM s, jewellery shops etc. There was a shortage of newly designed notes in the banks which caused a strike on the bottom of the commercial sector of the Indian economy. India's GDP and industrial production decreased, service sectors affected in a bad manner, micro-business and seasonal business hampered due to huge cash shortage.

It is also interesting to note that this was not the first time that Govt. of India has gone for demonetization of high value currency. It was first implemented in 1946 when the Reserve Bank of India demonetized the then circulated Rs. 1000 and Rs 10000 notes. The Government then introduced higher denomination banknotes in Rs 1000, Rs 5000 
and Rs 10000.In January 1978, the Indian Govt. had demonetized Rs 1000,Rs 5000 and Rs 10000 notes to counter black money in the economy.

The main focus of this paper is small scale businessmen and how they have affected because of this decision. Many reports stated that small scale businessmen have immensely affected after demonetization because of the cash crunch and lack of infrastructure like digital payment system etc. Small traders in retail sector (grocery shops etc), service sector (restaurants, nursing homes etc.), gems and jewellery, small traders in agricultural products, SMEs, small dealers, professionals like doctors, lawyers etc, have highly affected because of demonetization during last one year.

Cooch Behar is a small district town of West Bengal which is closely connected with Assam, Siliguri, Bhutan and Bangladesh and a good amount of businesses are transacted by the small business traders to these places. The study I have conducted among the small businessmen in Cooch Behar District specially the small dealers, stockiest and grocery shop owners actually may reflect the entire countries scenario for small traders and impact of demonetization on them in India.

\section{Problem Statement}

Typically, most of the small businessmen have between Rs 1 lakh and Rs 10 lakhs of cash in hand. The only exceptions are owners of tannery and gems businesses. They keep a couple of crores of rupees in hand because these businesses are entirely run on cash. So, in the first four-five days of demonetization, the small businesses tried to figure out what to do with the old notes of Rs 500 and Rs 1,000. They could deposit Rs 2.5 lakhs in their accounts and also in those of members of their families. By and large, small enterprises didn't encounter much of a problem in disposing of their cash in a legal way. In the second stage small business owners have seen they don't have money to pay suppliers, transporters, loaders and labourers. Payments to them constitute a large percentage their expenditure. They didn't have money because they had deposited it, but banks didn't give them money in return. It is then they realised that they faced a depressing future. In worst case, rules regarding withdrawal and deposit of money were being changed all the time. The most important thing for business is predictability. A businessman takes corruption in his stride, whether in Bihar or the Northeast. About 7\% to $8 \%$ of people are employed in government and corporate sectors. Of the remaining $92 \%$, take out $60 \%$ of those who are farmers or linked to the rural economy, though they too work on cash and not cheques. The remaining $32 \%$ or a little more is employed in small scale enterprises and depends on cash. Demonetization has had an adverse impact on a lot of those who don't have black money. Chemotherapy in cancer treatment is opted as a last resort. This is because chemotherapy also kills healthy cells. To eradicate black money, the micro, small and medium enterprises were thus hit badly.

\section{Literature Review:}

G. Ganesan et.al.(2017) conducted a study on the impact of demonetization on Indian Economy. This study depicts that there is a positive effect of demonetization in long run. It also states that agricultural sectors, real estate sectors are affected by this move in the short run but there must be a positive growth in the long run.

Geeta Rani(2016) researched on the effect of demonetization on retail outlets. This study states that at initial stage shopkeepers faced huge problems and the markets were very much affected by the cash crunch but this move also compelled the shopkeepers and consumers to adopt cashless means which will create a sound or hassle free transaction process in the future.

Ashok K.Nag(2016) revealed in his paper 'Lost due to demonetization' how this vacuum cleaning of money supply affects negatively the businessmen, wage earners, self employers as well as GDP of the country.

\section{Research Objectives:}

Some research objectives are formulated

- To study the effect of demonetization on small scale enterprises with special reference to Cooch Behar District after one year.

- To study whether daily transactions of small businessmen have any effect on digitization of their transaction method or not. 
- To study whether after one year the digital payment methods have adopted by the businessmen have significantly increased or not.

- To study after one year whether the corruption has been reduced or not as per corruption percentage index.

- To study some significant impact of demonetization on Indian economy after one year.

Hypothesis

$\mathbf{H}_{01}$ : There is no significant difference between daily transactions of small businessmen and their usage of digital payment system

\section{Methodology}

This study is an empirical study and based on secondary as well as primary data. Secondary data have been collected from different sources like RBI reports, IMF financial access survey reports, FITCH rating reports and other sources. For primary data collection from various small scale businessmen like shop owners, stockiest or dealers at Cooch Behar District of West Bengal a questionnaire of 15 questions is prepared. The sample size determined as 40 and the questionnaire had been circulated as per convenient sampling method.

\section{Analysis \& Findings}

RBI cut its GDP growth forecast in FY2017-18 to 7.1\%, FITCH ratings lowered India's GDP growth forecast to $6.9 \%$, the US based rating agency Morgan Stanley has also revised GDP growth forecast to $7.4 \%$ which are not a good sign for Indian economy.

Table1: Gross Domestic Product Forecast (FY: 2017-18)

\begin{tabular}{|l|c|c|}
\hline Institutions & Before Demonetization (\%) & After Demonetization (\%) \\
\hline RBI & 7.6 & 7.1 \\
\hline Fitch & 7.4 & 6.9 \\
\hline Morgan Stanley & 7.7 & 7.4 \\
\hline
\end{tabular}

Regarding currency ban US based rating agency Morgan Stanley said investment scenario in India is still uncertain. The objective of Government to make India cashless economy has long way to go. India is still one of the most cash intensive economies in the world with a cash to GDP ratio of $12 \%$.A boost of electronic payments is welcome as the spin offs include automatic audit trials, transparent accounting and minimizing the risk and cost of handling cash, but India is a vastly unbanked country and many among the poor do not have bank accounts. So to expect people in rural India to switch to plastic in a short span seems unrealistic.

Table2: Cashless Transactions and where India stands

\begin{tabular}{|l|l|}
\hline \multicolumn{1}{|c|}{ Country } & \multicolumn{1}{c|}{ Cashless Transactions } \\
\hline Singapore & $61 \%$ \\
\hline Netherlands & $60 \%$ \\
\hline France & $59 \%$ \\
\hline Sweden & $57 \%$ \\
\hline Canada & $57 \%$ \\
\hline Belgium & $56 \%$ \\
\hline UK & $52 \%$ \\
\hline USA & $45 \%$ \\
\hline Australia & $35 \%$ \\
\hline South Korea & $29 \%$ \\
\hline Spain & $16 \%$ \\
\hline Brazil & $15 \%$ \\
\hline Japan & $14 \%$ \\
\hline China & $10 \%$ \\
\hline India & $2 \%$ \\
\hline
\end{tabular}

(Source: Master Card Advisors)

There are around 2.17 lakhs ATMs are in India which are very less comparing to other countries like China. In India there are only 19.71 ATM machines per 1, 00,000 adults whereas in China the number of ATMs are 254.13 for 1, 
00,000 adults. The above table clearly shows that how far India is in cashless transaction comparing to other countries. The basic infrastructure is not built up and India has taken a big move on demonetization.

It is expected that the demonetization may have a detrimental effect on small businessmen. In consumer durable sales like TV, Refrigerator, Washing machine dropped a greatest sum after demonetization while it has been improving from the last quarter of 2017.Demand for Gems and jewellery has declined drastically. Sale of high finished retail products have declined. Service sectors like restaurant services, private educational institutes have affected, local vegetable sellers have affected immensely. Small grocery shops, kirana shops have faced a huge cash crunch and till now they are affected. The table below shows how car market has drastically effected.

Table 3: Sales of car before and after demonetization

\begin{tabular}{|l|l|l|l|}
\hline Segment wise sales & Dec-15 & Dec-16 & Change (\%) \\
\hline Passenger vehicles & 230959 & 227824 & $1.40 \%$ \\
\hline Commercial vehicles & 56840 & 53966 & $5.10 \%$ \\
\hline Two wheelers & 1167621 & 910235 & $22.00 \%$ \\
\hline Three wheelers & 46894 & 29904 & $36.20 \%$ \\
\hline
\end{tabular}

(Source: http://www.siamindia.com)

From primary data survey 13 important questions were asked to the 40 small businessmen whose daily transactions vary between Rs 5000 to Rs 50000.A questionnaire was surveyed using a likert scale 0 to 4 . Where SD=Strongly Disagree, $\mathrm{D}=$ Disagree, NA/ND=Neither Agree/Nor Disagree, A=Agree, SA=Strongly Agree. Some results are furnished below

Table: 4 Feedback from Small Business owners at Cooch Behar District, WB

\begin{tabular}{|c|c|c|c|c|c|c|c|}
\hline & Questions Asked to small businessmen $(n=40)$ & SD & D & NA/ND & $\mathbf{A}$ & SA & Percentage \\
\hline 1 & Demonetization is successful in India? & 22 & 8 & 1 & 6 & 3 & $\operatorname{SD}(55 \%)$ \\
\hline 2 & Till now black money exists in India? & 1 & 2 & 0 & 11 & 26 & $\mathrm{SA}(65 \%)$ \\
\hline 3. & $\begin{array}{l}\text { Objective of reducing corruption and black money } \\
\text { fulfilled? }\end{array}$ & 5 & 10 & 4 & 5 & 16 & $\mathrm{SA}(40 \%)$ \\
\hline 4 & $\begin{array}{l}\text { Demonetization will bring prosperity in common } \\
\text { man's life }\end{array}$ & 18 & 8 & 4 & 7 & 3 & $\operatorname{SD}(45 \%)$ \\
\hline 5 & Demonetization will reduce terrorism in the country? & 6 & 6 & 1 & 8 & 19 & $\mathrm{SA}(48 \%)$ \\
\hline 6 & $\begin{array}{l}\text { Demonetization has an effect on your business till } \\
\text { now? }\end{array}$ & 1 & 1 & 0 & 3 & 35 & $\operatorname{SA}(88 \%)$ \\
\hline 7 & Digital payment system exists in outlet? & 25 & 5 & 0 & 6 & 4 & SD(63\%) \\
\hline 8 & $\begin{array}{l}\text { Faced any problem in your daily transaction after } \\
\text { demonetization? }\end{array}$ & 3 & 5 & 1 & 7 & 24 & $\mathbf{S A}(60 \%)$ \\
\hline 9 & $\begin{array}{lllll}\text { Business has been } & \text { reduced } \\
\text { demonetization? }\end{array}$ & 1 & 1 & 0 & 5 & 33 & $\mathbf{S A}(\mathbf{8 3 \%})$ \\
\hline 10 & $\begin{array}{l}\text { There is a positive effect of demonetization on small } \\
\text { businesses? }\end{array}$ & 25 & 10 & 1 & 2 & 2 & $\operatorname{SD}(63 \%)$ \\
\hline 11 & $\begin{array}{l}\text { Most customers are paying through digital payment } \\
\text { systems now }\end{array}$ & 27 & 7 & 0 & 3 & 3 & $\operatorname{SD}(68 \%)$ \\
\hline 12 & $\begin{array}{l}\text { Businessmen dealing most business transactions } \\
\text { through cheques? }\end{array}$ & 6 & 14 & 2 & 8 & 10 & $\mathrm{D}(35 \%)$ \\
\hline 13 & $\begin{array}{l}\text { Businessmen dealing most transactions through cash } \\
\text { till now? }\end{array}$ & 2 & 5 & 0 & 6 & 27 & $\mathrm{SA}(68 \%)$ \\
\hline
\end{tabular}

From the above table-4 it is clear that demonetization is not successful according to the feedback of the small business owners. Most of the respondents believe that black money till exists .Most of the respondents believe that demonetization did not bring any prosperity in common man's life. But most respondent believe that it may reduce the terrorism in our country. The respondents believe that demonetization had a significant effect on their business and the picture is not good. They do not believe that digital payment system has significantly increased rather most of the customers are paying through cash. Some of the businessmen are using POS but customers prefer to pay in cash rather than their debit/credit cards. 
This study is done in a small town like Cooch Behar but the result shows that throughout India the scenario may be same. Though Indian economy is quite strong and it is turning out to be better but the overall impact of demonetization was not good.

A null hypothesis was taken to check whether daily transactions have any effect on digital payment system or not.

$\mathbf{H}_{\mathbf{0 1}}$ : There is no significant difference between daily transactions of small businessmen and their usage of digital payment system

Daily transactions of the shop owners and their digital usage have taken as two variables and a one way ANOVA is done. The table below shows the value of $\mathrm{F}$.

Table 5: ANOVA

DIGITAL USAGE

\begin{tabular}{|l|r|r|r|r|r|}
\hline & $\begin{array}{c}\text { Sum of } \\
\text { Squares }\end{array}$ & df & Mean Square & F & Sig. \\
\hline Between Groups & 33.886 & 12 & 2.824 & 1.686 & .126 \\
Within Groups & 45.214 & 27 & 1.675 & & \\
Total & 79.100 & 39 & & & \\
\hline
\end{tabular}

(Var: Daily transactions, Digital usage)

From above table-5 the $\mathrm{F}$ value is 1.686 and $\mathrm{p}>.05(\mathrm{i}, \mathrm{e} .0 .126)$ signifies that there are homogeneity of variances across the group. This means our $\mathbf{H}_{\mathbf{0 1}}$ is accepted. So usage of digital payment system does not depend on daily transactions.

\section{Conclusion}

Demonetization is an established practice in monetary policy to tackle black money. But as the Government expected the results are far away from the expectations. Initially people praised the government decision but in a bigger picture the effect of demonetization became reverse. Specially for the small farmers, sellers, merchants, daily wage labourers and traders have suffered a lot because of lack of proper planning, intelligence, infrastructure and foresight such as recalibration of ATM machines. There was need to pile up enough 100 Rupee notes and other smaller denomination notes in the market before taking this step. People are facing problems because the limit of withdrawal has not been kept at a higher level. The truth is that its design was fundamentally flawed. There was no "policy skeleton," no cost-benefit analysis, and no evidence that alternative policy options were considered. But one good thing we have observed the efficiency of the banking employees in the crucial period supported by RBI. The patience of the common men was tested throughout the year.

\section{References}

[1] Patil, D. (2016, December 5). Fringe Benefit of Demonetization: Credit Cost Falls Sharply for India Inc. Retrieved December 13, 2016, Economic-Times:http://economictimes.indiatimes.com/markets/stocks/news/fringebenefitofdemonetization-credit-cost-falls-sharply-for-india-inc/articleshow/55807934.cms

[2] Kumar, A. P. (2016). Demonetization and the Rule of Law. Economic and Political Weekly, 19-21.

[3] Rajkumar, J. D., \& Shetty, S. L. (2016). Demonetization: 1978, the Present and the Aftermath. Economic and Political Weekly, 13-17

[4] Dhume, S. (2016, December 15). India's Demonetization Debacle. Retrieved from Wall Street Journal: http://www.wsj.com/articles/indias-demonetization-debacle- 1481851086 Kumar, A. P. (2016). Demonetization and the Rule of Law. Economic and Political Weekly, 19-21.

[5] http://www.indianeconomy.net/splclassroom/309/what-are-the-impacts-of-demonitisation-on-indianeconomy/\#sthash.wIhn787q.dpuf

[6] http://www.moneycontrol.com/news/economy/impact-analysisdemonitizationindia 8044821.html?utm source=ref article 


\section{APPENDIX}

Dear Sir/Madam,

\section{Questionnaire}

Greetings!

We are conducting a research survey on Impact of Demonetization on Small Scale Enterprises at Cooch Behar. Hope the research findings will contribute in policy making. Kindly spare few minutes and fill up the questionnaire.

Name:

Name of Enterprise:

Number of Years in Business: 0-5yrs

Daily Transaction: Rs.5000-20000

$5-10 y r s$

$10-15 y r s \square 15-20 y r s$

Rs.20000-35000 $\square$ Rs.35000-50000

$>20 y r s$

(Please tick on $\mathrm{SD}=$ Strongly Disagree, $\mathrm{D}=$ Disagree, $\mathrm{NA} / \mathrm{ND}=$ Neither Agree nor Disagree, $\mathrm{A}=\mathrm{A}$ ,SA=Strongly Agree)

1. Demonetization is successful in India?

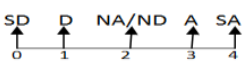

2. Till now black money exists in India? $\quad \begin{aligned} & \mathrm{SP} \\ & 0\end{aligned}$

3. Objective of reducing corruption and black money fulfilled?

4. Demonetization will bring prosperity in common man's life

5. Demonetization will reduce terrorism in the country? $\begin{gathered}\mathrm{SP} \\ 0\end{gathered}$

6. Demonetization has an effect on your business till now?

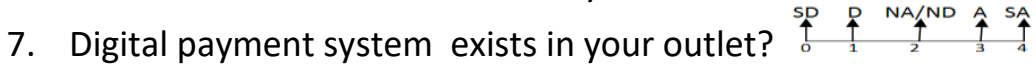

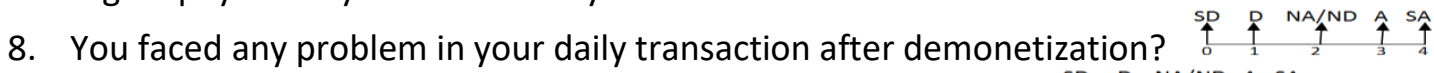

9. Your business has been reduced /down after demonetization?

10. If yes what problems you have faced?

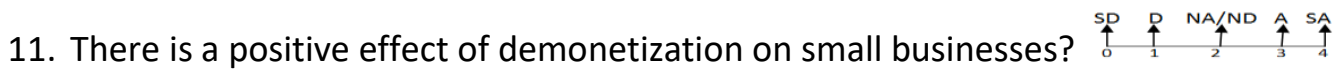

12. Most customers are paying through digital payment systems now (like Paytm or airtel money or other)?

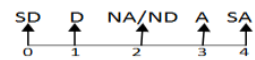

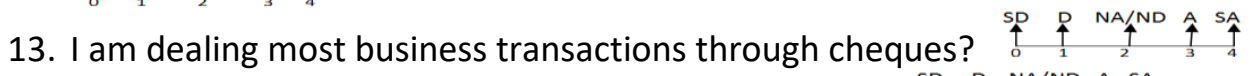

14. I am dealing most transactions through cash till now?

15. Any other comment or feedback on demonetization- 